\title{
Quality of life of patients with multiple sclerosis and urinary disorders: validation of Qualiveen
}

Qualidade de vida da pessoa com esclerose múltipla e disfunção urinária: validação do Qualiveen

Calidad de vida de la persona con esclerosis múltiple y disfunción urinaria: validación del Qualiveen

Cátia Patrícia Palhais Rodrigues*; Fernando Manuel Dias Henriques** (D)

\section{Abstract}

Background: Urinary disorders have a negative impact on the quality of life and social functioning of patients with multiple sclerosis and can even be more harmful than motor changes.

Objective: To perform the cultural and linguistic adaptation of Qualiveen (Brazilian Portuguese) and analyze its reliability and validity.

Methodology: It was done the evaluation of the conceptual and linguistic equivalences and then of the psychometric properties of the final Portuguese (European) version. The sample consisted of 72 individuals, who attended a hospital in the center of the country, between 12/3/2016 and 1/14/2017.

Results: The European Portuguese version of Qualiveen has conceptual and linguistic equivalence, showing an excellent reliability for the total scale (Cronbach's alpha of .96) and its subdomains (Cronbach's alpha of .81 and .93), as well as convergent and discriminant validity.

Conclusion: The European Portuguese version of Qualiveen showed adequate psychometric properties. For this reason, it can be used by the scientific community with the purpose of analyzing and describing the impact of urinary disorders on the health-related quality of life of patients with Multiple Sclerosis.

Keywords: quality of life; multiple sclerosis; urination disorders; psychometrics; validation studies

\section{Resumo}

Enquadramento: As disfunçóes urinárias representam um peso negativo a nível social e ao nível da qualidade de vida da pessoa com esclerose múltipla, sendo mesmo referenciadas como mais prejudiciais que as alteraçôes motoras.

Objetivo: Realizar a adaptação cultural e linguística do Qualiveen (português-Brasil), procedendo à análise da sua fiabilidade e validade.

Metodologia: Realizou-se a avaliaçáo das equivalências conceptuais e linguísticas e posteriormente das propriedades psicométricas da versão final do Qualiveen (português-Europeu). A amostra foi constituída por 72 indivíduos, que frequentaram um hospital na zona centro entre 03/12/2016 e 14/01/2017.

Resultados: A versão em português-Europeu apresentou equivalência conceptual e linguística, demonstrando uma excelente fiabilidade geral $(\alpha=0,96)$ e nas subdimensóes da escala $(0,81 \leq \alpha \leq 0,93)$, assim como validade convergente e discriminante.

Conclusáo: A versão do Qualiveen (português-Europeu) demonstrou propriedades psicométricas adequadas, pelo que pode ser utilizada pela comunidade científica, com o intuito de analisar e descrever o impacto que a disfunçáo urinária representa na qualidade de vida relacionada com a saúde da pessoa com esclerose múltipla.

Palavras-chave: qualidade de vida; esclerose múltipla; transtornos urinários; psicometria; estudos de validação

*RN, Specialist in Rehabilitation Nursing, Coimbra Hospital and University Center, 3000-075, Coimbra, Portugal [catiapprodrigues@gmail.com]. Contribution to the article: literature search, research design, data collection, statistical treatment and analysis, discussion of results. Address for correspondence: Urb. Quinta da Oliveira Torta, Lote 7, 2D, 3020-504 Coimbra.

**MSc., Coordinating Professor, Nursing School of Coimbra, 3046-851, Coimbra, Portugal [fernando@esenfc.pt]. (1) https://orcid.org/0000-0002-9919-4313. Contribution to the article: literature search, research design, study and article revision.

\section{Resumen}

Marco contextual: Las disfunciones urinarias representan un peso negativo a nivel social y a nivel de la calidad de vida de la persona con esclerosis múltiple, e incluso se indican como más perjudiciales que las alteraciones motoras.

Objetivo: Realizar la adaptación cultural y lingüística de Qualiveen (portugués de Brasil), mediante el análisis de la fiabilidad y la validez.

Metodología: Se llevó a cabo la evaluación de las equivalencias conceptuales y lingüísticas y más tarde de las propiedades psicométricas de la versión final del Qualiveen (portugués europeo). La muestra está constituida por 72 individuos, que asistieron a un hospital en la zona centro entre el 03/12/2016 y el 14/01/2017.

Resultados: La versión en portugués europeo presenta una equivalencia conceptual y lingüística, demuestra una excelente fiabilidad global $(\alpha=0,96)$ y en los subdominios $(0,81 \leq \alpha \leq 0,93)$, así como una validez convergente y discriminante.

Conclusión: La versión de Qualiveen (portugués europeo) ha demostrado propiedades psicométricas adecuadas, por lo que puede ser utilizada por la comunidad científica, con el fin de analizar y describir el impacto que la disfunción urinaria representa en la calidad de vida relacionada con la salud de las personas con esclerosis múltiple.

Palabras clave: calidad de vida; esclerosis múltiple; trastornos urinarios; psicometría; estudios de validación

Received for publication: 01.03 .18

Accepted for publication: 15.06 .18 


\section{Introduction}

Today, health-related quality of life plays an important role in health professionals' decision-making process (Stöhrer et al., 2009). This growing concern emerged from the human and biological sciences with the purpose of not only eliminating disease symptoms, increasing average life expectancy, and reducing mortality (Nader, 2016), but above all providing the best possible quality of life for all people regardless of their health status.

A chronic disease, particularly one with a variable evolution like multiple sclerosis, can cause intense feelings of anxiety and frustration and reduce patients' quality of life (Thompson \& Mauk, 2011).

Urinary disorders affect the person not only physically but also psychologically, namely by the fear of urine leaking and smelling bad, changes in the sleep patterns, and lack of rest due to nocturia, which leads to anxiety and fear. It can also have an impact on the social dimension, causing isolation and fear of contacting with other people (Ferreira, 2014). For these reasons, urinary disorders are often referred to as being more harmful than motor changes (Denys, Phe, Even, \& Chartier-Kastler, 2014).

Nurses focus their intervention on the patient's ability to live their life without interference from the disease or overcome its difficulties. It is important to intervene at an early stage and pay attention to all the signs and symptoms that may lead to dependence and discomfort with the purpose of reducing its consequences (Minayo, Hartz, \& Buss, 2000). It is essential to assess the impact of urinary disorders on patients with multiple sclerosis with a view to planning adequate interventions for reducing their impact on the quality of life of these patients.

The challenge is to find an easy-to-use measurement tool for clinical practice (Seidl \& Zannon, 2004). In Portugal, there is no data collection tool to assess both urinary disorders and the quality of life of people with neurological changes, at least one that covers all urinary disorders and that can be applied to both men and women.

The Qualiveen questionnaire aims to assess general and urinary-related impact on the quality of life of people with neurological disorders and multiple sclerosis (D'Ancona et al.,
2009). It is an extremely specific data collection tool which allows obtaining valid and reliable results for patients with multiple sclerosis. The Qualiveen is an originally French questionnaire which was translated and validated for Brazilian Portuguese by D'Ancona et al. (2009). Although instruments written in the same language, but from different cultures and countries, can be used if their equivalence is previously confirmed, they should be culturally and linguistically adapted, for which reason this study, after prior authorization (Beaton, Bombardier, Guillemin, \& Ferraz, 2000), aimed to perform the linguistic and cultural adaptation of the Brazilian Portuguese version of Qualiveen into European Portuguese, as well as analyze its reliability and validity.

\section{Background}

Instruments for measuring health-related quality of life are usually multi-dimensional and also assess the overall self-perception of quality of life, although the emphasis falls on disease-related symptoms, disabilities or limitations (Seidl \& Zannon, 2004).

Urinary disorders are a major problem and a significant cause of disability in patients with multiple sclerosis, affecting their social relationships and daily activities (Amarenco, de Sèze, Ruffion, \& Ismael, 2014) and, consequently, their quality of life. It is essential to find ways of identifying and measuring the impact of these changes on these patients lives. Although several instruments have been developed, according to Amarenco, Colvez, Costa, Didier, and Perrouin-Verbe (2003), none of them assessed the impact of urinary problems on the quality of life of people with neurological disorders.

A group of French physicians specialized in the areas of urology, physical medicine and rehabilitation, and epidemiology, together with experts in quality of life assessment and the Coloplast Laboratories developed a specific instrument: Qualiveen. This tool has three versions: the Qualiveen used in this study; Qualiveen-30; and SF-Qualiveen.

According to Bonniaud et al. (2004), disease-specific measurement tools have the potential for increased responsiveness and likeli- 
hood of elucidating the real problems of people with multiple sclerosis. Although specific instruments for people with multiple sclerosis are available, they are neither adequate nor specific for assessing their urinary problems. The more specific the instrument, the earlier the diagnosis of associated complications in people with multiple sclerosis (Denys et al., 2014).

Qualiveen is divided into two parts. The first part discusses the impact of urinary problems on the quality of life (IPUQV) through the analysis of four subdimensions: inconvenience (IPUQV-INC); restrictions (IPUQV-L); fears (IPUQV-P); and impact on daily life (IPUQV-IVD).

Inconvenience is assessed based on the patient's perception of some problems related to the presence of urinary dysfunction, urine leaks during the day, use of incontinence pads, pants, adult diapers or external urinary devices, the time spent passing urine, the sleep changes caused by urinary problems, personal hygiene problems, and problems when traveling.

The restrictions subdimension assesses the person's perception about the need to plan every activity in advance, the need to take incontinence pads, pants or adult diapers, as well as an extra change of clothes, and the need to limit the intake of fluids during the day and the time spent away from home.

In relation to fears, the questionnaire focuses on the smelling of urine, the possibility of having urinary infections, the worsening of bladder problems, urine leaks during sexual intercourse, the possibility of having drug-related side effects, having skin problems caused by urinary problems, and having money problems.

To assess the impact on daily life, the questionnaire focuses on the feelings of embarrassment, the possibility of feeling humiliation or anxiety, the discomfort with people's reaction to the increase of time spent in the bathroom, and the person's need to conceal the urinary problems.

The second part assesses the quality of life based on psychological well-being, autonomy, physical well-being, sexual relations, and social relationships. The questionnaire also includes a question which is not used to calculate the impact of urinary problems on the quality of life, but rather to identify patient's perceptions of how they pass urine.

\section{Methodology}

According to Nader (2016), there are multiple recommendations for the cultural and linguistic adaptation of an instrument, with one study finding 17 different methods and no consensus on the most appropriate ones. In this study, the authors followed the guidelines of Beaton et al. (2000) because they were the ones agreed upon when permission was obtained for the linguistic and cultural adaptation of the Brazilian Portuguese version from the Coloplast Laboratories, which own the copyright to Qualiveen.

After the formal authorizations were obtained from the translator and the legal owner, this two-phase process began. The first phase included six steps. In the first step (translation), the instrument was translated by the researcher, who was familiar with the questionnaire's concepts, and a teacher with a degree in Translation and Portuguese Studies, who was not familiar with the subject or the concepts (both of them had Portuguese nationality). This step aimed to avoid errors and misinterpretations.

In the second step (synthesis), both translators translated the instrument to reach a consensual version.

Then, in the back-translation step, the instrument was translated based on the common version into the questionnaire's language of origin. This back-translation was only performed once because the back-translated version showed a high level of agreement with the original version.

In the fourth step (consensus panel), a panel of seven experts was convened: a Brazilian nurse enrolled in a Ph.D. in Nursing; a nurse and professor of Rehabilitation Nursing; a professor with a degree in Translation and Portuguese Studies: domain of Portuguese/English; a head nurse of a neurology department who had a specialization in Rehabilitation Nursing and a Postgraduate degree in Multiple Sclerosis Nursing; a head nurse of an urology department who had a specialization in Rehabilitation Nursing; and two nurses of an urology department.

This committee aimed to ensure that the data collection tool was perfectly understandable and that the introduction and instructions were clear and understandable, which is why the panel was composed of experts in the Por- 
tuguese language (European and Brazilian Portuguese) and experts in urology and neurology. A pre-final version was achieved with the participants' contributions. Any discrepancies were solved using the decentering technique, that is, starting from the assumption that the original and translated tools are equally important.

The content, semantic, conceptual, and linguistic equivalence of the pre-final version was ensured. The fact that a person from Brazil also integrated the panel ensured the conceptual equivalence of contents, that is, the presence of experts from Brazil and Portugal ensured that the translated items described relevant phenomena for both cultures.

The presence of a translation expert was of utmost importance to ensure semantic equivalence, guaranteeing that, after translation, the meaning of the items remained the same in both versions. The presence of the nursing rehabilitation experts was also important because, together with the professor and the other panel members, they ensured the conceptual equivalence, which attested to the validity of the concepts in both cultures.

The remaining panel members were nurses from urology and neurology departments who provided highly significant contributions as the instrument covers both two areas. The sharing of knowledge and skills among the panel members ensured the linguistic equivalence of the pre-final version.

Thus, the pre-final version was consensual and fully satisfactory, as it is recommended by Fortin (2009).

Then, in the pre-test step, the data collection tool was applied in the same setting where the study was conducted.

After the assessment of its conceptual and linguistic equivalence, the second phase began with the assessment of its psychometric properties.

No data collection tool, either new or culturally adapted, is linguistically valid without reliability and validity tests (Cardoso, 2006).

There are several ways to assess the reliability of an instrument. As it was difficult to have access to the same individuals and ensure that all of them were not exposed to conditions which could change their answers to specific domains, the authors decided to study reliability without using the retest process, essentially due to the unpredictability of the disease under analysis in this sample.
Reliability of the consensual version of the questionnaire was assessed using Cronbach's alpha coefficient $(\alpha)$ with a view to analyzing its internal consistency, which is based on the possible correlations between two sets of items within the same questionnaire. Cronbach's alpha coefficient can range from 0 to 1 , being that the closer to 1 , the more consistent, that is, the more reliable the instrument. The following internal consistency values proposed by Pestana and Gageiro (2014) were applied: alpha values exceeding 0.90 - very good; alpha values between 0.80 and 0.90 - good; alpha values between 0.70 and 0.80 - reasonable; alpha values between 0.60 and 0.70 - poor; and alpha values less than 0.60 - unacceptable.

The analyzed items should have at least a Cronbach's alpha of 0.70 for internal consistency.

To measure reliability, the split-half method was used, in which the total data set is divided into two equivalent sets and the scores are correlated using the Spearman-Brown formula. The measure is reliable if the standard deviation is low or the coefficient of reliability (correlation) is high.

The Spearman-Brown correlation coefficient can range from +1 to -1 . If the value is close to +1 , it indicates a perfect positive correlation between the items; if zero, it indicates that there is no correlation between the items; and if - 1 , it indicates a perfect negative correlation between the items. The closer to zero, the weaker is the inter-item correlation.

This coefficient has the advantage of not being influenced by the events that occur between both moments of application of the same questionnaire to the same people, making it often difficult to interpret the results obtained in the test-retest (Pestana \& Gageiro, 2014).

The validity of a data collection tool is not easy to ascertain (Cunha, Neto, \& Stackfleth, 2016). Validity refers to the degree to which the results are correctly observed, that is, the accuracy with which a particular concept is measured (Cardoso, 2006).

With regard to validity, Hill and Hill (2012) believe that a data collection tool is neither valid nor not valid, but rather that there are degrees of validity. The validation of a scale does not reflect if the scale is valid or not, but rather that it is valid for a given context, because validation is a never-ending process (Polit, Beck, \& Hungler, 2004). 
The validity of a data collection tool is assessed based on its content, conceptual, and criterion validity. This latter was not assessed in this study because no other instrument was used to assess the same construct.

Content validity is based on judgment; there is no method capable of ensuring that the data collection tool represents the entire universe of a given construct (Polit et al., 2004).

Conceptual validity aims to analyze whether the data collection tool measures what it is theoretically intended to measure about the construct (Fortin, 2009). To perform this analysis, convergent and discriminant validity were analyzed using the multitrait-multimethod matrix which assesses the correlations between the items of the scale and its subdomains (Fortin, 2009). This analysis was also performed to the original version of the scale.

This analysis aims to explore the correlations between items and subdimensions and identify if the statistically higher correlation found is allocated to the subdimension which the item belongs in the original scale. Convergent validity is met if the correlation between an item and the dimension to which it belongs is higher than 0.30 . Discriminant validity is met if the correlation between an item and the dimension to which it belongs is statistically higher than with the other dimensions, that is, values closer to $100 \%$ indicate better discriminant validity (Santos, Deon, Bullinger, \& Santos, 2014).

The nonprobability accidental sample was composed of 72 patients with multiple sclerosis and lower urinary tract symptoms who attended the nursing consultation or day hospital of a neurology department of a Portuguese central hospital between 3 December 2016 and 14 January 2017.

This type of sample does not allow for the equal selection of all participants, but it is the quickest and easiest way to have access to individuals as this was a small-sized and difficult-to-access population. It is estimated that the population in Central Hospital is composed of 876 individuals.

The following inclusion criteria were applied: having a clinical diagnosis of multiple sclerosis, having urinary changes, having the cognitive ability to answer the questionnaire, knowing how to read and write, and being over 18 years of age.
The following patients were excluded: pregnant women, women with gynecological conditions, with the diagnosis of urinary tract infection but not medicated and women who were medicated but still had infection-related urinary tract changes, and men with diagnosed and untreated prostate disease.

A favorable opinion (No. 195/CES; CHUC034-16) was obtained from the Board of Directors and the Ethics Committee of the Hospital, as well as from the director and head nurse of the department where the study was conducted. The study was explained to all participants who gave their informed consent in writing.

\section{Results}

In the pre-test, the participants had no doubts about understanding and interpreting the items of the Qualiveen, with most of them reporting that it was easy to complete. There were no questionnaires with unanswered items.

During the first phase of assessment of its linguistic and conceptual equivalence, the most significant changes were associated with idiomatic expressions in the data collection tool. In the Brazilian Portuguese version, the expression "coletor externo" was replaced by "dispositivo urinário externo" in the European Portuguese version. Similarly, in the first area of the questionnaire, the expression "de maneira nenhuma" was replaced by "nunca" and, in question 3, "por ter que usar absorventes ou forros/coletor externo?" was replaced by "por ter que usar absorventes ou (pensos, fralda ou cueca)/dispositivo urinário externo/sonda vesical?". In the second area, in questions 15 and 16, the type of continence products was described "(pensos, fralda ou cueca)" and, in the area of quality of life assessment, "ruim" was replaced by "mal", "um pouco ruim" by "relativamente mal", and "um pouco bem" by "relativamente bem".

In order to investigate the psychometric properties, the reliability of the consensual version of Qualiveen was analyzed through Cronbach's alpha coefficient.

A Cronbach's alpha coefficient of 0.96 was obtained in the items assessing the impact of urinary problems on health-related quality of life, as well as of 0.81 to 0.93 in the four subdimensions (Table 1). 
The European Portuguese version of Qualiveen showed very good internal consistency in the assessment of the impact of urinary problems on health-related quality of life, as well as in its subdimensions. It also showed a good internal consistency of the items on the quality of life, with a Cronbach's $\alpha$ of 0.88 .
These data are of utmost importance because reliability coefficients are an important indicator of the quality of the instruments, as well as for the interpretation of the results. An instrument with low reliability prevents adequate testing of the research questions (Polit et al., 2004).

Table 1

Internal consistency of Qualiveen - European Portuguese using Cronbach's $\alpha$

\begin{tabular}{lccc}
\hline Scale subdimensions & Scale items & $\begin{array}{c}\text { Number of scale } \\
\text { items }\end{array}$ & Cronbach's $\alpha$ \\
\hline Inconvenience & $1-9$ & 9 & 0.93 \\
Restrictions & $10-17$ & 8 & 0.90 \\
Fears & $18-25$ & 8 & 0.81 \\
Impact on daily life & $26-30$ & 5 & 0.90 \\
Impact of urinary disorders on health-related & $1-30$ & 30 & 0.96 \\
quality of life & $31-39$ & 9 & 0.88 \\
Quality of life & & & \\
\hline
\end{tabular}

When compared to the original scale and the Brazilian Portuguese version, all of them had

values higher than 0.90 (Table 2).

Table 2

Cronbach's $\alpha$ - Qualiveen (different versions)

\begin{tabular}{lc}
\hline Qualiveen & Cronbach's $\alpha$ \\
\hline Original version (French) & 0.92 \\
Portuguese (Brazilian) & 0.90 \\
Portuguese (European) & 0.96 \\
\hline
\end{tabular}

The correlation between both parts of the questionnaire was also analyzed through the splithalf method, in which the total dataset was divided in half and its correlations were analyzed using the Spearman-Brown formula. A coefficient of 0.95 was found, which means that there is a positive and very strong correlation between both halves of the questionnaire.

Thus, this version proved to have an excellent reliability.

For the analysis of content validity, this study did not aim to analyze the universe of the construct because Qualiveen is a data collection tool designed by experts in the area and, in 2009, it was considered the only specific tool for the assessment of the health-related quality of life of patients with urinary and neurological disorders by the European Urology Association (Stöhrer et al., 2009). Based on the opinion of the consensus panel experts, the Qualiveen, through its subdimensions, measures exactly what it is intended to measure: the inconvenience caused by urinary disorders, the restrictions that occur due to the presence of urinary problems, the fears due to the presence of urinary problems, the impact of urinary problems on daily life, the overall quality of life, and the patient's perception of how they pass urine.

In order to check for the conceptual validity of the European Portuguese version of Qualiveen, convergent and discriminant validity was analyzed (Table 3). 
In Table 3, the values in bold correspond to the items of the subdimensions to which they belong and the underlined values correspond to the highest correlation value of the item that does not belong to the subdimensions where it is included.

Table 3

Multitrait-multimethod analysis of Qualiveen - European Portuguese

\begin{tabular}{|c|c|c|c|c|}
\hline Item & IPUQV-INC & IPUQV-L & IPUQV-P & IPUQV-IVD \\
\hline 1 & $0.83^{* *}$ & $0.76^{* *}$ & $0.68^{* *}$ & $0.73^{* *}$ \\
\hline 2 & $0.73^{* *}$ & $0.57^{* *}$ & $0.65^{* *}$ & $0.53^{* *}$ \\
\hline 3 & $0.82^{* *}$ & $0.71^{* *}$ & $0.73^{* *}$ & $0.71^{* *}$ \\
\hline 4 & $0.81^{* *}$ & $0.64^{* *}$ & $0.67^{* *}$ & $0.64^{* *}$ \\
\hline 5 & $0.66^{* *}$ & $0.48^{* *}$ & $0.48^{* *}$ & $0.60^{* *}$ \\
\hline 6 & $0.63^{* *}$ & $0.52^{* *}$ & $0.46^{* *}$ & $0.47^{* *}$ \\
\hline 7 & $0.92^{* *}$ & $0.82^{* *}$ & $0.69^{* *}$ & $0.77^{* *}$ \\
\hline 8 & $0.85^{* *}$ & $0.78^{* *}$ & $0.64^{* *}$ & $0.73^{* *}$ \\
\hline 9 & $0.89^{* *}$ & $0.87^{* *}$ & $0.75^{* *}$ & $0.78^{* *}$ \\
\hline 10 & $0.69^{* *}$ & $0.84^{* *}$ & $0.54^{* *}$ & $0.62^{* *}$ \\
\hline 11 & $\underline{0.67^{* *}}$ & $0.64^{* *}$ & $0.49^{* *}$ & $0.57^{* *}$ \\
\hline 12 & $0.40^{* *}$ & $0.50^{* *}$ & $0.35^{* *}$ & $0.36^{* *}$ \\
\hline 13 & $0.73^{* *}$ & $0.81^{* *}$ & $0.58^{* *}$ & $0.72^{* *}$ \\
\hline 14 & $0.70^{* *}$ & $0.83^{* *}$ & $0.48^{* *}$ & $0.62^{* *}$ \\
\hline 15 & $0.76^{* *}$ & $0.86^{* *}$ & $0.70^{* *}$ & $0.71^{* *}$ \\
\hline 16 & $0.76^{* *}$ & $0.86^{* *}$ & $0.61^{* *}$ & $0.69^{* *}$ \\
\hline 17 & $0.64^{* *}$ & $0.75^{* *}$ & $0.61^{* *}$ & $0.59^{* *}$ \\
\hline 18 & $0.66^{* *}$ & $0.56^{* *}$ & $0.79^{* *}$ & $0.59^{* *}$ \\
\hline 19 & $0.59^{* *}$ & $0.46^{* *}$ & $0.73^{* *}$ & $0.51^{* *}$ \\
\hline 20 & $0.42^{* *}$ & $0.33^{* *}$ & $0.69^{* *}$ & $0.37^{* *}$ \\
\hline 21 & 0.16 & 0.13 & $0.45^{* *}$ & 0.11 \\
\hline 22 & $0.43^{* *}$ & $0.36^{* *}$ & $0.58^{* *}$ & $0.26^{*}$ \\
\hline 23 & $0.46^{* *}$ & $0.34^{* *}$ & $0.59^{* *}$ & $0.38^{* *}$ \\
\hline 24 & $0.67^{* *}$ & $0.65^{* *}$ & $0.68^{* *}$ & $0.51^{* *}$ \\
\hline 25 & $0.68^{* *}$ & $0.66^{* *}$ & $0.69^{* *}$ & $\underline{0.73^{* *}}$ \\
\hline 26 & $0.72^{* *}$ & $0.66^{* *}$ & $0.61^{* *}$ & $0.90^{* *}$ \\
\hline 27 & $0.66^{* *}$ & $0.61^{* *}$ & $0.50^{* *}$ & $0.85^{* *}$ \\
\hline 28 & $0.57^{* *}$ & $0.44^{* *}$ & $0.51^{* *}$ & $0.77^{* *}$ \\
\hline 29 & $0.51^{* *}$ & $0.46^{* *}$ & $0.35^{* *}$ & $0.72^{* *}$ \\
\hline 30 & $0.80^{* *}$ & $0.85^{* *}$ & $0.69^{* *}$ & $0.88^{* *}$ \\
\hline
\end{tabular}

Note. IPUQV-INC = Qualiveen Inconvenience subdimension; IPUQV-L = Qualiveen Restrictions subdimension; IPUQV-P = Qualiveen Fears subdimension; IPUQV-IVD = Qualiveen Impact on daily life subdimension; ${ }^{*} p<0.05 ;{ }^{* *} p<0.01$. 
In relation to convergent validity, after the analysis of Spearman's correlation coefficients, the results showed that the correlations between the items and the subdimensions (areas) to which they belong were statistically significant for $p<0.01$ higher than 0.30 .

With regard to discriminant validity, two items had a higher statistically significant correlation with another subdimension than the subdimension to which they belonged, which corresponds to approximately $93.33 \%$ for discriminant validity.

Item 11, "Às vezes desiste de sair de casa?", had a higher correlation with the IPUQV-INC subdimension, although it belonged to the IPUQV-L subdimension. However, the correlational difference between both subdimensions was low and had a higher correlation with the subdimension to where it belonged than with the other two subdimensions.

Item 25, "Preocupa-se com os problemas financeiros causados pelas despesas devido aos seus problemas urinários?", had a higher correlation with the IPUQV-IVD subdimension, although it belongs to the IPUQV-P subdimension. However, the correlational difference between both subdimensions was low and had a higher correlation with the subdimension to where it belonged than with the other two subdimensions.

Thus, the results showed that the items are adequately distributed by the constructs, keeping the same conceptual organization of the original version of Qualiveen.

\section{Discussion}

It is important to use simple and reliable data collection tools to monitor the health-related quality of life of patients with multiple sclerosis and urinary disorders and, consequently, allow health professionals to intervene early with a view to maintaining or recovering these patients' health and enabling them to remain professionally active and psychologically healthy.

Qualiveen was not culturally and linguistically adapted to the Portuguese population, thus the authors decided to perform its cultural and linguistic adaptation.

The results revealed an excellent reliability, with a Cronbach's alpha of 0.96 for the total scale and values ranging from 0.81 to 0.93 for its four subdimensions, which are similar results to those found in the original version and the Spanish and Brazilian Portuguese versions (Amarenco et al., 2003; Ciudin et al., 2012; D’Ancona et al., 2009). Moreover, the split-half method revealed an excellent internal consistency, with a reliability coefficient of 0.95 (Polit et al., 2004).

After confirming that it was a reliable instrument, the authors analyzed its convergent and discriminant validity through the multitrait-multimethod matrix, as in the original version of the scale (Amarenco et al., 2003). The results revealed that the scale had convergent and discriminant validity.

Although the sample size for the linguistic and cultural adaptation of a data collection tool is not consensual according to Pestana and Gageiro (2014), it must be associated with the number of items; however, similarly to the sample of 51 individuals used for the translation and validation of the Brazilian Portuguese version of Qualiveen by D'Ancona et al. (2009), the sample of 72 individuals was considered acceptable taking into account the limited time frame of this study.

This limitation could have been overcome with more time for data collection and/or additional research sites.

The objective of this study was accomplished because it aimed to provide the scientific community with a valuable, valid, and reliable data collection tool for health professionals, namely nurses, to assess and monitor the impact of these problems and, then, education and train these patients on how to cope with their urinary problems, thus reducing their inconvenience, restrictions, fears, and impact on daily life. This questionnaire can be used as long as it is for non-commercial purposes and with the owners' permission.

However, further studies should validate the Qualiveen with a large sample of neurological diseases, as well as validate the SF-Qualiveen, which is a shorter version that would be more easily applied in the scientific community.

\section{Conclusion}

The Qualiveen was culturally and linguisti- 
cally adapted to the Portuguese population. It showed an excellent reliability, as well as convergent and discriminant validity. For this reason, it can be used by the scientific community.

\section{References}

Amarenco, G., Colvez, A., Costa, P., Didier, J. P. \& Perrouin-Verbe, B. (2003). Manual del usuario y guía de interpretación Qualiveen. Retrieved from http://www. aeu.es/UserFiles/ManualQualiveen.pdf

Amarenco, G., de Sèze, M., Ruffion, A., \& Ismael, S. S. (2014). Clinical and urodynamic evaluation of urinary disorders in multiple sclerosis. Annals of Physical and Rehabilitation Medicine, 57(5), 277-287. doi: 10.1016/j.rehab.2014.05.006

Beaton, D. E., Bombardier, C., Guillemin, F., \& Ferraz, M. B. (2000). Guidelines for the process of cross-cultural adaptation of self-report measures. Spine, 25(24), 3186-91.

Bonniaud, V., Parratte, B., Amarenco, G., Jackowski, D., Didier, J. P. \& Guyatt, G. (2004). Measuring quality of life in multiple sclerosis patients with urinary disorders using the Qualiveen questionnaire. Archives of Physical Medicine and Rehabilitation, 85(8), 1317 1323. doi: 10.1016/j.apmr.2003.09.029.

Cardoso, I. (2006). Aspectos transculturais na adaptação de instrumentos de avaliação psicológica. Interacçôes: Sociedade e as novas modernidades, 10, 98-112.

Ciudin, A., Franco, A., Diaconu, M. G., Peri, L., Vivas, V., Gonzalez, M. A. \& Alcaraz, A. (2012). La calidad de vida de los pacientes con esclerosis múltiple: Traducción y validación de la versión en castellano de Qualiveen. Annals d'Urologia, 38, 20-23.

Cunha, C. M., Neto, O. P., \& Stackfleth, R. S. (2016). Principais métodos de avaliação psicométrica da validade de instrumentos de medida. Revista de Atenção à Saúde, 14(47), 75-83. doi: 10.13037/ras.vol14n49.3671

D’Ancona, C. A., Tamanini, J. T., Botega, N., Lavoura, N., Ferreira, R., Leitão, V., \& Lopes, M. H. (2009). Quality of life of neurogenic patients: Translation and validation of the Portuguese version of Qualiveen. International Urology and Nephrology, 41(1), 29-33. doi: 10.1007/s11255-008-9402-3

Denys, P., Phe, V., Even, A., \& Chartier-Kastler, E. (2014).
Therapeutic strategies of urinary disorders in MS: Practice and algorithms. Annals of Physical and Rehabilitation Medicine, 57(5), 297-301. doi: 10.1016/j. rehab.2014.05.003

Ferreira, A. P. (2014). Efeito de um programa de treinamento do assoalho pélvico na qualidade de vida de mulheres com esclerose múltipla (Master's dissertation). Universidade Federal de Mato Grosso do Sul, Campo Grande, Brasil.

Fortin, M. (2009). Fundamentos e etapas do processo de investigação. Loures, Portugal: Lusodidacta.

Hill, M. M., \& Hill, A. (2012). Investigação por questionário (2a ed.). Lisboa, Portugal: Ediçôes Silabo.

Minayo, M. C., Hartz, Z. M., \& Buss, P. M. (2000). Qualidade de vida e saúde: Um debate necessário. Ciência e Saúde Coletiva, 5(1), 7-18. doi: 10.1590/S141381232000000100002

Nader, B. B. (2016). Tradução, validação e adaptação cultural do Questionário Qualiveen Short Form (Master's dissertation). Universidade Estadual de Campinas, Faculdade de Ciências Médicas, Brasil.

Pestana, M. H., \& Gageiro, J. N. (2014). Análise de dados para ciências sociais: A complementaridade do SPSS (6 $6^{\mathrm{a}}$ ed.). Lisboa, Portugal: Ediçóes Sílabo.

Polit, D. F., Beck, C. T., \& Hungler, B. P. (2004). Fundamentos de pesquisa em enfermagem: Métodos, avaliação e utilização ( $5^{\mathrm{a}}$ ed.). Porto Alegre, Portugal: Artmed.

Santos, D. M., Deon, K. C., Bullinger, M., \& Santos, C. B. (2014). Validade do instrumento DISABKIDS ${ }^{\oplus}$ : Módulo fibrose cística para crianças e adolescentes brasileiros. Revista Latino-Americana de Enfermagem, 22(5), 819-825. doi: 10.1590/0104-1169.3450.2485

Seidl, E. M., \& Zannon, C. M. (2004). Qualidade de vida e saúde: Aspectos conceituais e metodológicos. Cadernos de Saúde Pública, 20(2), 580-588. doi: 10.1590/ S0102-311X2004000200027

Stöhrer, M., Blok, B., Castro-Diaz, D., Chartier-Kastler, E., Denys, P., Kramer, G., . . Wyndaele, J.-J. (2009). Orientaçóes sobre disfunção neurogénica do tracto urinário inferior. Retrieved from http://www.apurologia.pt/ guidelines/Disf-Neurog-Tract-Urin-Inf.pdf

Thompson, H. J., \& Mauk, K. L. (Eds.). (2011). Nursing management of the patient with multiple sclerosis: AANN, ARN, and IOMSN Clinical Practice Guideline Series. Retrieved from http://iomsn.org/wp-content/uploads/2016/07/AANN-ARN-IOMSN-MSGuideline_FINAL.pdf 
